\title{
,new \\ Nature-Based Solutions in Poland against Climate Change
}

\author{
Edyta Małecka-Ziembińska ${ }^{1, *(1)}$ and Izabela Janicka ${ }^{2, *}$
}

1 Department of Public Finance, Institute of Finance, Poznań University of Economics and Business, al. Niepodległości 10, 61-875 Poznan, Poland

2 Department of Information Economics, Institute of Socio-Economics, Poznań University of Economics and Business, al. Niepodległości 10, 61-875 Poznan, Poland

* Correspondence: Edyta.Malecka-Ziembinska@ue.poznan.pl (E.M.-Z.); Izabela.Janicka@ue.poznan.pl (I.J.)

Citation: Małecka-Ziembińska, E.; Janicka, I. Nature-Based Solutions in Poland against Climate Change. Energies 2022, 15, 357. https:// doi.org/10.3390/en15010357

Academic Editor: Aleksy Kwilinski

Received: 5 December 2021

Accepted: 30 December 2021

Published: 4 January 2022

Publisher's Note: MDPI stays neutral with regard to jurisdictional claims in published maps and institutional affiliations.

Copyright: (c) 2022 by the authors. Licensee MDPI, Basel, Switzerland. This article is an open access article distributed under the terms and conditions of the Creative Commons Attribution (CC BY) license (https:// creativecommons.org/licenses/by/ $4.0 /)$.

\begin{abstract}
One of the currently promoted methods of counteracting climate change is nature-based climate solutions, which harness the power of nature to reduce greenhouse gas emissions. Sustainable management of ecosystems is a guarantee for sustained human well-being. This underestimated, but extremely efficient and cheap method of integrating nature resources into the urban fabric is an economic "injection" for communal authorities. These "green" benefits should be standard in land-use planning in the era of anthropocentrism. Solutions based on nature were the reason for investigating their perception by Polish municipalities. The survey covered the entire country (all 2477 municipalities) from 20 July to 31 August 2021 through an electronic survey, obtaining 2128 responses (85.9\% return rate). In the final result, data were obtained that support the hypotheses posed in the study. The main objective of the research was to check the level of activity of municipalities in Poland in the field of proecological activities using nature-based solutions ( $\mathrm{NbS}$ ). The survey results confirmed little knowledge of nature-based solutions, at the same time giving it an educational dimension. Half of the respondents declared that they learned about NbS only from the survey. Polish decision makers and municipal authorities introduce some solutions based on nature without being aware of their European classification and adequate nomenclature. Environmental awareness in Poland remains largely the domain of urban municipalities, with higher current budget revenues per capita and in the central and western parts of the country. $\mathrm{NbS}$ are marginal in rural municipalities, which can be explained by the lack of ecological specialists, less car traffic and more single-family houses and thus modest public areas. The following surveys covering the entire territory of Poland are the first to be carried out on such a large scale.
\end{abstract}

Keywords: nature-based solutions; climate change; sustainable development; Poland

\section{Introduction}

Climate change is one of the most important challenges of the 21 st century. It is the subject of worldwide public debate, viewed from different perspectives [1-4].

The warming of the Earth's climate is a fact. "The average temperature of the earth's surface is rising as a result of the increased concentration of carbon dioxide and other greenhouse gases in the atmosphere owing to human activities, especially the burning of fossil fuels, coal, oil, and gas. This global warming will lead to substantial changes of climate, many of which will impact human communities in deleterious ways" [5]. In addition to numerous fires, floods, waterlogging and droughts, species extinction and biodiversity loss are occurring [6,7]. Higher temperatures and extreme weather events promote increased illness and even infectious disease outbreaks, plus people with allergies will be exposed to an increase in seasonal allergen production [8,9]. As temperatures rise, heat-related mortality also increases [10]. The disruption of nature's balance has created favorable conditions for the spread and emergence of pathogens that are transmitted from wild and domestic animals to humans [11,12]. Urbanization affects ecosystems [13], and 
already half of humanity lives in urban areas [14]. Disaster sizes can be reduced by naturebased solutions $(\mathrm{NbS})$, which have always adapted to climate change. It only needs to be "enabled" to do so, as disasters are not caused by extreme events per se, but occur when a society's ability to cope with an extreme event is overstretched or mismanaged. For these reasons, the term "natural disaster" is now considered "misleading" [15].

Nature-based solutions are still a novelty in research regarding their relationship to sustainable development, and are subject to constant scrutiny of the public interest. Naturebased solution projects are proposed for sponsors, researchers, and policy makers [16,17], and proven examples of solutions in some European cities are presented [18,19]. In connection with climate change, innovative opportunities are emphasized through synergies between nature, society and the economy, which directly translates into a green, sustainable and competitive economy [20]. Climate change on Earth is forcing a new approach to nature, which is the primary, nonrenewable resource for human life and functioning. Establishing a European Green Deal (Proposal for the regulation of the European Parliament and of the Council Establishing the Framework for Achieving Climate Neutrality and Amending Regulation (EU) (European Climate Law) Brussels, 4.3.2020 COM/2020/80 Final, 2020/0036 (COD), n.d.) [21] is the European Union's response to the needs of citizens to preserve environmental values and maintain quality of life. The development of civilization has transformed the housing structure, as a result of which more than $50 \%$ of the world's population lives in cities, and according to UN estimates, this number will exceed $80 \%$ by 2050 . Nature-based solutions provide an alternative to repair, maintain and control ecosystems, and working with nature increases their resilience to the effects of climate change. Even small strips of green maintain proper soil structure, retain water and provide shelter from strong winds or snowstorms. Nature-based solutions are a chance to create ecological standards in Poland and their implementation may increase the absorption of EU funds. Polish researchers have rightly noticed that the concept of NbS "should sell easily in Poland and other post-socialist and post-transition countries, where neoliberal (economic) ideas have caught on. In fact, the new socio-economic system introduced in Poland as a result of transformation from a socialist country should in theory create a window of opportunity for new" [22].

The motivation of this study was to identify and determine the level of involvement of Polish municipalities in NbS-based proenvironmental processes, which are an indispensable condition for building stable conditions for safe human functioning in a changing environment. On its condition, diversity and abundance depends on the health of people and comfort of living. The indirect aim of the study was $\mathrm{NbS}$ promotion and examining the level of perception of NbS issues in the activities and strategic plans of municipalities.

The following research questions were posed. Does the type of municipality and the number of its inhabitants influence the introduced restrictions on the use of cars? Does the type of municipality and its population affect the development of green architecture? As per capita current income rises, does environmental awareness also rise, resulting in greater pressure on authorities and thus the number of environmental staff employed locally?

In order to obtain answers, a questionnaire survey was carried out in all 2477 municipalities in Poland, obtaining 2128 answers (85.9\% return rate). The survey covered all types of municipalities due to the possible similarity of activities undertaken. However, they can vary in intensity and scale. Even particularly favorable environmental conditions, such as the presence of forests, lakes and fields in rural areas, do not exempt municipalities from keeping this well-being intact. The functional structure of municipalities was not taken into account, although this is important in proecological activity. However, $\mathrm{NbS}$ are not strictly related to the economic situation of the municipality, and their use does not deplete financial resources, and may even bring additional profits. Additionally, municipalities operating in green enclaves (located in naturally rich areas) do not have a guarantee of the existence of this environment in the future, because the climate and polluted air are a nationwide problem. 
The article consists of an Introduction (1), four sections (2-5) and Conclusions and recommendations (6). Section 2 presents an understanding of $\mathrm{NbS}$ and their international capture. Section 3 presents the $\mathrm{NbS}$ and the structure of local government in Poland. Section 4 is a presentation of the objectives, hypotheses and research method, and Section 5 describes the results of the study and discussion. The article concludes with Conclusions and recommendations (6).

\section{Understanding $\mathrm{NbS}$ and Its International Coverage}

The term nature-based solutions has been defined by the UNESCO specialist organization, the International Union for Conservation of Nature and Natural Resources (IUCN), with the words, "Actions to protect, sustainably manage and restore natural or modified ecosystems that address societal challenges effectively and adaptively, simultaneously providing human well-being and biodiversity benefits" [23].

The European Commission understands $\mathrm{NbS}$ as "Nature-based Solutions to societal challenges as solutions that are inspired and supported by nature, which are cost-effective, simultaneously provide environmental, social and economic benefits and help build resilience. Such solutions bring more, and more diverse, nature and natural features and processes into cities, landscapes and seascapes, through locally adapted, resource-efficient and systemic interventions" [24].

According to the European Commission

Green infrastructure (GI) is a strategically planned network of natural and seminatural areas with other environmental features designed and managed to deliver a wide range of ecosystem services. It incorporates green spaces (or blue if aquatic ecosystems are concerned) and other physical features in terrestrial (including coastal) and marine areas. On land, GI is present in rural and urban settings [25].

The concept of $\mathrm{NbS}$ has evolved over the years through IUCN and the EC and is always included in debates on climate change adaptation, ecosystem services or green infrastructure [26]. The blue-green infrastructure is an NbS solution that complements the traditional "grey" and blends perfectly into the urban landscape. Its main purpose is to retain rainwater, absorb carbon dioxide, reduce air pollution and mitigate the urban heat-island effect [27]. Examples of NbS include: bioretention ditches, infiltration ditches, rain gardens, green roofs and building facades or sheds, and permeable paving. They all regulate the flow of water, air, and any urban greenery reduces temperature, which translates into energy savings [28] and human health [29,30].

In addition to these concepts, there are other nature-derived solutions that help meet low-carbon energy needs through production methods derived from natural sources such as wind, wave and solar energy. While these sources come from the natural world, they are not directly based on functioning ecosystems. The same applies to the term nature-inspired solutions. This is the innovative design and fabrication of materials of structures and systems that are modeled on and that mimic biological processes, e.g., biomimicry. They are in no way based on functioning ecosystems (IUCN).

Among the 17 Sustainable Development Goals (SDGs) adopted by the UN General Assembly on 25 September 2015, in the form of the 2030 Agenda for the Eradication of Poverty, are actions to address climate change and its impacts. Goal 13 (SDG 13) also includes increasing education and awareness on climate change mitigation [31].

Over the past two decades, the impact of natural disasters has been devastating, affecting more than 4 billion people, including killing more than 1 million and causing approximately USD 2.9 trillion in economic losses. Traditional "grey" solutions with dominant concrete are giving way to $\mathrm{NbS}$ for water management. Since 2012, the World Bank has integrated NbS in about 100 projects in 60 countries. The Bank supports urban flood protection by maintaining wetlands in Colombo, Sri Lanka, and restored mangroves prevent flooding and coastal erosion in Vietnam. In 2012, the Bank developed a comprehensive study on sustaining water resources through nature-based solutions in East Asia. The Bank is also involved in knowledge enhancement, such as hosting the Urban Flood Community 
of Practice (UFCOP) website on the role of green infrastructure in urban flood risk management. The World Bank has also released a booklet called Managing Coasts with Natural Solutions [32], with guidelines from the WAVES partnership on measuring and protecting coastlines, mangroves and coral reefs [33].

In the European Union (EU), NbS have been part of the research and innovation funding program since 2014, aligning the biodiversity and ecosystem services strategy with innovation for growth and job creation [34]. More recently, the EU Green Deal [35] recognized the key role of $\mathrm{NbS}$ in creating a net zero society by 2050, as well as in climate change adaptation and mitigation in the widely supported $\mathrm{NbS}$ manifesto from the UN Climate Action Summit [36].

On climate change mitigation, the OECD highlighted the importance of $\mathrm{NbS}$ as a tool for systemic action in many sectors of the economy. It assessed the feasibility of using $\mathrm{NbS}$ to improve water quality and manage flood risk and scarcity as the most cost-effective way [37]. Among OECD countries, instruments to encourage the use of $\mathrm{NbS}$ at the national level include: the EU's Horizon 2020 Framework Programme for Research and Innovation, from which the EU has allocated EUR 185 million for research and pilot deployment of $\mathrm{NbS}$ between 2014 and 2020, or Canadian dollar 1.6 billion Adaptation Fund to help local communities manage flood risk, droughts and other hazards [38].

\section{NbS and Local Government in Poland}

On 29 October 2013, the Council of Ministers adopted the Strategic Adaptation Plan for Sectors and Areas Sensitive to Climate Change by 2020 with an Outlook to 2030, the so-called SPA2020-Polish National Strategy for Adaptation to Climate Change (NAS2020). This document was developed based on the results of a research project called KLIMADA "Development and implementation of a strategic adaptation plan for sectors and areas vulnerable to climate change", carried out on behalf of the Ministry of Environment in 2011-2013 with funding from the National Fund for Environmental Protection and Water Management (NFEPWM). It is part of the EU's framework policy, which aims to improve Member States' resilience to climate change and thus mitigate the associated socioeconomic costs. Among the sources of financing the measures for adaptation to climate change are national public funds from the NFEPWM, provincial funds for environmental protection and water management, the state budget, revenues from the sale of AAUs (Assigned Amount Units) and the budgets of local government units. The latter are additionally recommended for EU funds under the New Financial Perspective, which finance instruments for sustainable urban development.

The conclusions and recommendations do not address the identification of NbS in any of the six Polish National Strategy objectives. Close to this idea are recommendations for territorial self-government units, such as: renaturalization of watercourses, development of small retention, development of alternative energy sources, increasing green and water areas in cities, and in actions to reduce the health effects of thermal stress, only a more effective system of health protection is proposed. Territorial self-government units have also been assigned educational and awareness-raising tasks with respect to risks associated with extreme phenomena and the promotion of ecological behavior. It is hoped that the training provided by municipalities takes into account the $\mathrm{NbS}$ [39].

The Ministry of Environment in the document "National Environmental Policy 2030" emphasizes the strong impact of climate change on numerous sectors of the economy, as well as society. According to the report, there are "regions in Poland, e.g., urbanized or with intensive agriculture, where degradation of nature and impoverishment of species composition is progressing. Adverse changes in the abundance and composition of plant and animal species most often result from faulty spatial management: rapid, uncontrolled urban development, settlements spreading within naturally valuable areas or in their immediate vicinity, crossing ecological corridors by transport infrastructure, unification and impoverishment of landscapes" [40]. According to the Ministry, "some environmental problems still require intensified action. It is necessary to bring about a more efficient 
use of resources, in such a way that the increasing level of consumption and affluence of Poles does not cause further burden on the environment, including, above all, exceeding air quality standards, unacceptable level of surface water pollution, reducing the level of biodiversity or exposure of the population to noise" [40].

In view of the signaled threats, it is necessary not only to take measures on a national scale, but also to direct and stimulate communes towards proenvironmental development. The authors propose nature-based solutions that in most cases work more efficiently and are more cost-effective [34]. This model minimizes organizational and cost barriers, so often raised by Polish small municipalities, and additionally has a positive image for "green" activity. The added value is higher environmental awareness of the residents, without whose involvement ecotransformation will not be possible.

The rest of this section presents the structure of administrative divisions and local government in Poland.

In Poland, public administration operates on two levels: the state and territorial selfgovernment. The state administrates its territory, establishes legislation, guarantees public security, manages the economy, ensures minimum subsistence for its citizens as well as establishes and finances higher education institutions, theaters and national museums.

Local government is organized into three tiers: municipalities (gmina), districts (powiat) and regions/voivodships (województwo). As of 1 January 2021, there were 16 regions (voivodships), 314 districts and 2477 municipalities. Municipalities and districts have a local nature and regions are the highest level of local government. The municipality is the basic unit of local government. The districts perform tasks exceeding the competencies of municipalities, while regions are responsible for tasks that are beyond the competencies of municipalities and districts. The levels of local government are independent of each other and have different sources of financing.

There are three types of municipalities: urban, which comprise towns; rural, which comprise the countryside and urban-rural, which comprise towns with the surrounding countryside. Some of the urban municipalities have a specific status: one administrative center performs the tasks of both the municipality and the district at the same time. These are called cities with district rights. These units do not form a separate level of local government and are still classified as municipalities. The tasks of local government are presented in Figure 1.

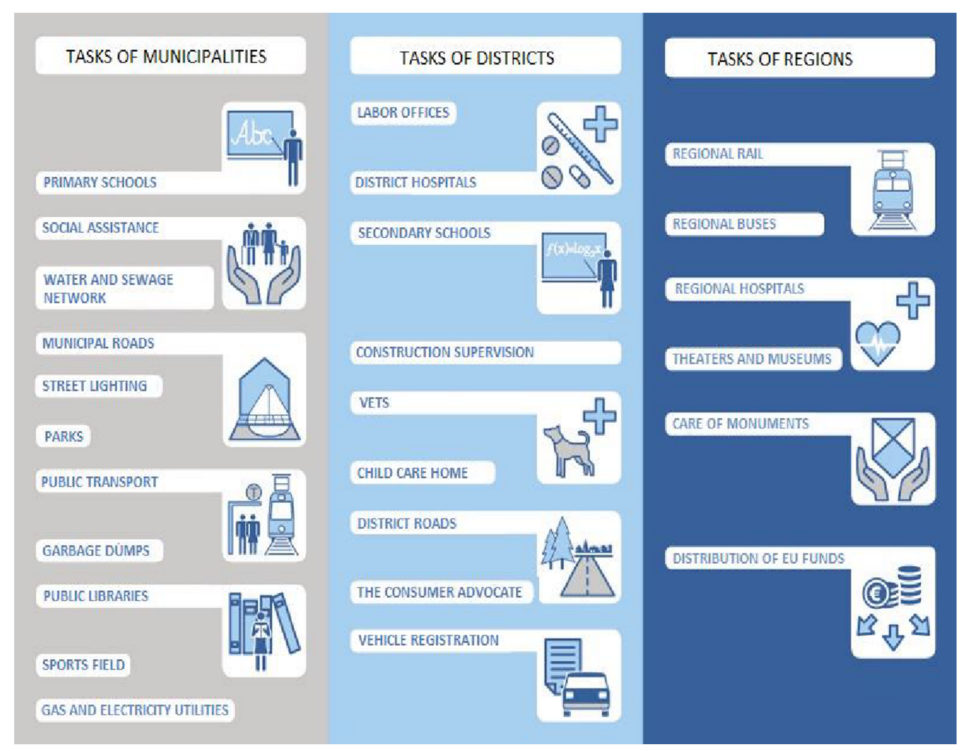

Figure 1. Tasks of local government in Poland. Source: [41].

Among the municipalities, 302 are urban municipalities, including 66 cities with district rights, 652 urban-rural municipalities and 1523 rural municipalities. This study focuses on municipalities, including cities with district rights. All municipalities perform 
the same compulsory tasks and have the same sources of income but their financial standing is different for objective reasons, such as the number of residents, not for legal status.

Pursuant to Article 7 Clause 1 of the Act on Local Self-Government, the municipality's own tasks include care for spatial order, real estate management, environmental and nature protection and water management [42]. "The most important role is assigned to planning instruments, ensuring rational organization of activities in the municipality in the field of environmental protection. This includes both municipal environmental protection programs, municipal waste management plans" [43]. The environmental action plan implemented by the commune is the commune's ecodevelopment program. Due to the limitations of the powers to protect water and air from pollution, the available opportunities for activity are local spatial planning, protection of green spaces and some agricultural and forestry species [44,45].

The majority of communes, out of concern for the proper standard of living of their inhabitants, carry out many additional tasks, the effects of which have a direct impact on people's health and life, business attractiveness and the economic development of the commune. Proenvironmental actions require long-term plans and sometimes large financial outlays. In the long run, however, they can become an added value for the municipality. Technological changes towards a low-carbon, circular economy require high financial, human and know-how support. For this reason, it is worth paying attention to $\mathrm{NbS}$ (nature-based/nature-inspired solutions) or nature-inspired solutions for adapting cities to climate change. They have no Polish equivalent. They are also often confused with green infrastructure.

In the Polish public space, green infrastructure is understood as any piece of greenery that does not always meet the following NbS standards, as the solutions that are proposed here must do [46]:

- cost-effective (economically efficient),

- providing environmental, economic and social benefits at the same time,

- to support adaptation to climate change,

- $\quad$ adapted to local conditions,

- resource-efficient.

Additionally, there are economic benefits to implementing them with the support of landscaping professionals and with the cooperation of residents. The priority of the $\mathrm{NbS}$ is to preserve the green and blue elements already existing in the urban fabric, maintaining natural watercourses, retention basins, squares, individual trees, parks, green belts that have a natural permeable surface. It is more important to maintain and expand than to plant. Adapting greenery to local conditions does not require a lot of money and intensive care or irrigation. This applies to any vegetation that has access to native soil in urban settings. Thus, they meet the $\mathrm{NbS}$ criteria, i.e., provide environmental, economic and social benefits at the same time. The lawns so prevalent in cities do not fall into this category.

In Poland - so far-only fragmentary studies of NbS implementation have been conducted, focusing mainly on large cities [47]. Similarly, worldwide research in this area is comparative or fragmentary and mainly concerns urban agglomerations. An overview of these studies is available, inter alia, in [48] and many other NbS publications. For example, Kabisch et al. [49] reviewed the health outcomes associated with accessing green/blue spaces as NbS to help reduce risk factors related to urbanization. Moreover, Zölch et al. [50] provide evidence of the effectiveness of urban green infrastructure as an NbS in regulating stormwater, and help planners/operators of sewage systems select the most effective measures to implement and assess their impact. In order to demonstrate the range of applications of the $\mathrm{NbS}$ concept, case studies (10 cases) for solving a selected social problem were presented. Additionally, the ways of using $\mathrm{NbS}$ in various types of ecosystems and in various regions of the world were indicated [23]. Using Barcelona and Shanghai as case studies, Fan et al. [51] examined nature-based solutions in urban settings-specifically within cities experiencing postindustrialization and globalization. In turn, Van der Jagt et al. [52] studied six communal urban gardening (CUG) initiatives from five EU countries 
representing different planning regimes and traditions. They selected cases taking a locally unique or innovative approach to dealing with urban challenges. A variety of actors associated with each of the cases were interviewed to achieve as complete a picture as possible regarding important governance arrangements. A cross-case comparison revealed a range of success factors, varying from clearly formulated objectives and regulations, municipal support, financial resources and social capital through to the availability of local food champions and facilitators engaging in community building.

The conducted study fills the research gap, as it covers all municipalities in Poland, and its results provide information on the knowledge and use of NbS across the country.

\section{Aims, Hypotheses and Research Method}

The Figure 2 below demonstrates the stages of the study.

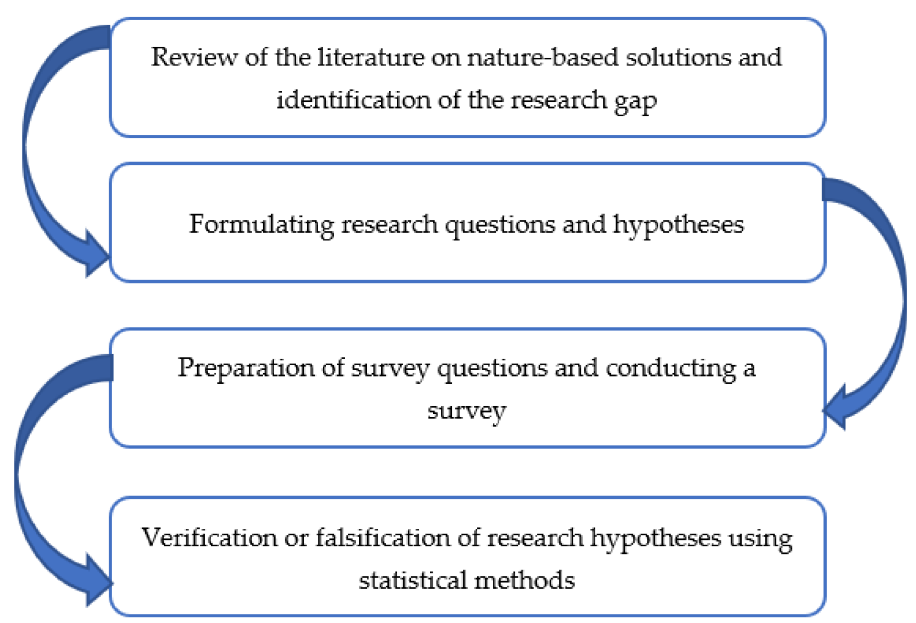

Figure 2. Stages of the study. Source: authors' study.

The aim of the paper is to answer the research questions specified in the Introduction. The following hypotheses were made:

Hypothesis 1. (H1). The size and type of municipalities determine the actions used to reduce auto use. As the population of the municipality increases, the use of such measures increases. Cities with county status in particular offer bike/scooter rentals, park $\mathcal{E}$ ride facilities near public transport points and car sharing to a greater extent than other municipalities.

Hypothesis 2. (H2). There is a correlation between the assessment of green space development and the size and type of municipality. For architectural reasons, green areas are developed especially in large municipalities that are urban municipalities.

Hypothesis 3. (H3). The size and type of municipalities determine the measures applied to the green architectural landscape. As the population of the community increases, the use of measures to increase the 'green' landscape increases. However, such measures are not linked to current income per capita and the number of employees in the authority's environmental protection unit.

Hypothesis 4. (H4). Measures to improve thermal comfort are forced to be introduced mainly by large urban municipalities with a large number of inhabitants, where the architecture is more urbanized. However, such measures are still rare, with blue-green infrastructure features in close residential areas being the most common.

In order to verify or falsify the research hypotheses, an electronic survey was conducted in all (2477) municipalities in Poland. The survey was conducted from 20 July 2021 to 31 August 2021, as of 30 June 2021. As a result of electronically distributed questionnaires, 2128 responses were received, and the return rate was $85.9 \%$. 
The questionnaires were filled in by employees from the municipality's environmental unit. They answered the following questions:

1. How did the office find out solutions based on nature resources?

a. From this survey

b. From another office or external private entity

c. From the media (TV, press, internet) or during a conference

d. Based on your own actions

e. Another answer

2. In order to limit the use of cars, the commune (multiple answers possible):

a. Builds bicycle paths

b. Offers bicycle/scooter rentals

c. Has a park \& ride car park on its premises, located near public transport points

d. Offers carsharing and/or promotes carpooling

e. None of the above

3. In order to increase the number of green areas, the commune (multiple answers possible):

a. Conducts regular plantings with a predominance of native plant species

b. Runs and maintains flower meadows

c. Develops/greening atypical surfaces

d. Uses ground cover in place of lawns

e. None of the above

4. For the "green" architectural landscape of the commune (multiple answers possible):

a. Install green stops/shelters/roofs

b. Arranges interiors and communal surroundings in a biophilic design style

c. Applies vegetation resistant to road pollution on the lanes between roads

d. Maintains open fruit and vegetable gardens and/or creates and maintains pocket gardens

e. None of the above

5. In order to reduce the effects of heat waves and to improve thermal comfort, the commune (multiple answers possible):

a. Introduces elements of blue-green infrastructure in dense residential buildings

b. Modifies road and street surfaces reflecting sunlight/increases the albedo by modifying the surface of roads and pavements/or uses permeable surfaces

c. Installs floating gardens

d. Performs restitution and irrigation of wetlands

e. None of the above

The following descriptive statistics were used to verify or falsify research hypotheses:

Pearson's $\chi^{2}$ test: A nonparametric test to examine the relationship between two variables measured on a qualitative scale. This verifies the null hypothesis about the lack of relationship between the variables. In the case of a statistically significant result $p<0.05$, the null hypothesis is rejected in favor of the alternative one which states that there is a relationship between the variables. The Pearson coefficient $\chi^{2}$ is described by the formula:

$$
\chi^{2}=\sum_{i=1}^{n} \frac{\left(O_{i}-E_{i}\right)^{2}}{E_{i}}
$$

where: $O_{i}$-observed number, $E_{i}$ - expected number.

The strength of a relationship is measured by the Cramer $V$ coefficient: $0-0.3$ is a weak compound, $0.3-0.5$ a moderate compound, and $0.5-1$ a strong compound, which is calculated from the formula:

$$
V=\sqrt{\frac{\chi^{2}}{n \cdot \min (k-1, r-1)}}
$$


where: $n$-sample size, $k$-number of levels of one variable, $r$-number of levels of the second variable.

Spearman's rho correlation analysis: a nonparametric test to investigate the relationship between two variables measured on a quantitative or ordinal scale. Verifies the null hypothesis about the lack of relationship between the variables. In the case of a statistically significant result $p<0.05$, the null hypothesis is rejected in favor of the alternative one which states that there is a relationship between the variables. The direction and strength of the relationship is determined by the rho coefficient. In the case of a positive correlation, the high level of one variable is associated with the high level of the other variable. In the case of a negative correlation, the high level of one variable is associated with the low level of the other variable. The rho coefficient is defined by the formula:

$$
\text { rho }=1-\frac{6 \sum_{i=1}^{n} d_{i}^{2}}{n\left(n^{2}-1\right)}
$$

where: $d_{i}$-difference between positive and negative ranks, $n$-number of observations.

The questionnaire survey was conducted on a group of $N=2128$ municipalities, of which the majority were rural municipalities $(60.2 \%)$, followed by urban-rural municipalities $(26.8 \%)$, with a smaller proportion of responses from urban municipalities $(10.5 \%)$ and cities with county rights (2.5\%). The distribution of answers by type of municipalities corresponds to their distribution on the national scale (more on the number and types of municipalities in Poland in Section 3). The surveyed municipalities were mostly characterized by the number of inhabitants up to $10,000(63.8 \%)$ or between $10,000-20,000(22.4 \%)$, and a smaller group were municipalities with a larger number of inhabitants. The group of municipalities surveyed was dominated by those with current income per capita of either up to EUR 650 (36.6\%) or more than EUR 1083 (33.3\%). In terms of the number of employees in the office unit dealing with environmental protection, municipalities with up to two employees $(67.2 \%)$ or between three and five employees $(20 \%)$ prevailed. The characteristics of the surveyed municipalities are presented in Table 1.

Table 1. Characteristics of the surveyed municipalities.

\begin{tabular}{|c|c|c|c|c|c|}
\hline Specification & $N$ & $\%$ & Specification & $N$ & $\%$ \\
\hline Type of Municipality & \multicolumn{5}{|c|}{$\begin{array}{l}\text { Number of Employees in the Office's Unit } \\
\text { Dealing with Environmental Protection }\end{array}$} \\
\hline Urban municipality & 223 & $10.5 \%$ & Up to 2 persons & 1430 & $67.2 \%$ \\
\hline Rural municipality & 1281 & $60.2 \%$ & $3-5$ persons & 425 & $20.0 \%$ \\
\hline Urban-rural municipality & 571 & $26.8 \%$ & 6-10 persons & 122 & $5.7 \%$ \\
\hline City with county rights & 53 & $2.5 \%$ & More than 10 persons & 151 & $7.1 \%$ \\
\hline $\begin{array}{l}\text { Number of Inhabitants } \\
\text { (2020, Thousands) }\end{array}$ & \multicolumn{5}{|c|}{ Current Budget Revenue Per Capita (2020, EUR) } \\
\hline Up to 10 & 1357 & $63.8 \%$ & Below 650 & 779 & $36.6 \%$ \\
\hline $10-20$ & 477 & $22.4 \%$ & $650-758$ & 149 & $7.0 \%$ \\
\hline $20-30$ & 133 & $6.3 \%$ & $758-867$ & 69 & $3.2 \%$ \\
\hline $30-40$ & 50 & $2.3 \%$ & $867-975$ & 123 & $5.8 \%$ \\
\hline $40-50$ & 34 & $1.6 \%$ & $975-1083$ & 300 & $14.1 \%$ \\
\hline $50-100$ & 50 & $2.3 \%$ & Above 1083 & 708 & $33.3 \%$ \\
\hline Above 100 & 27 & $1.3 \%$ & & & \\
\hline
\end{tabular}

In terms of regions (Figure 3), the surveyed municipalities were dominated by municipalities from Mazowieckie, Wielkopolskie, Lubelskie, Małopolskie, Łódzkie and Śląskie voivodships (the largest unit of the three-tier territorial division of the country, regional self-government community, the whole country is divided into 16 such units). The small- 
est number of municipalities in the surveyed group came from Opolskie and Lubuskie voivodeships. This results directly from the fact that they are voivodships with the smallest number of municipalities. This is indirectly related to the declining population since 2013 due to migration outflow and low birth rate. Population density per $1 \mathrm{~km}^{2}$ of land area is also low nationally [53].

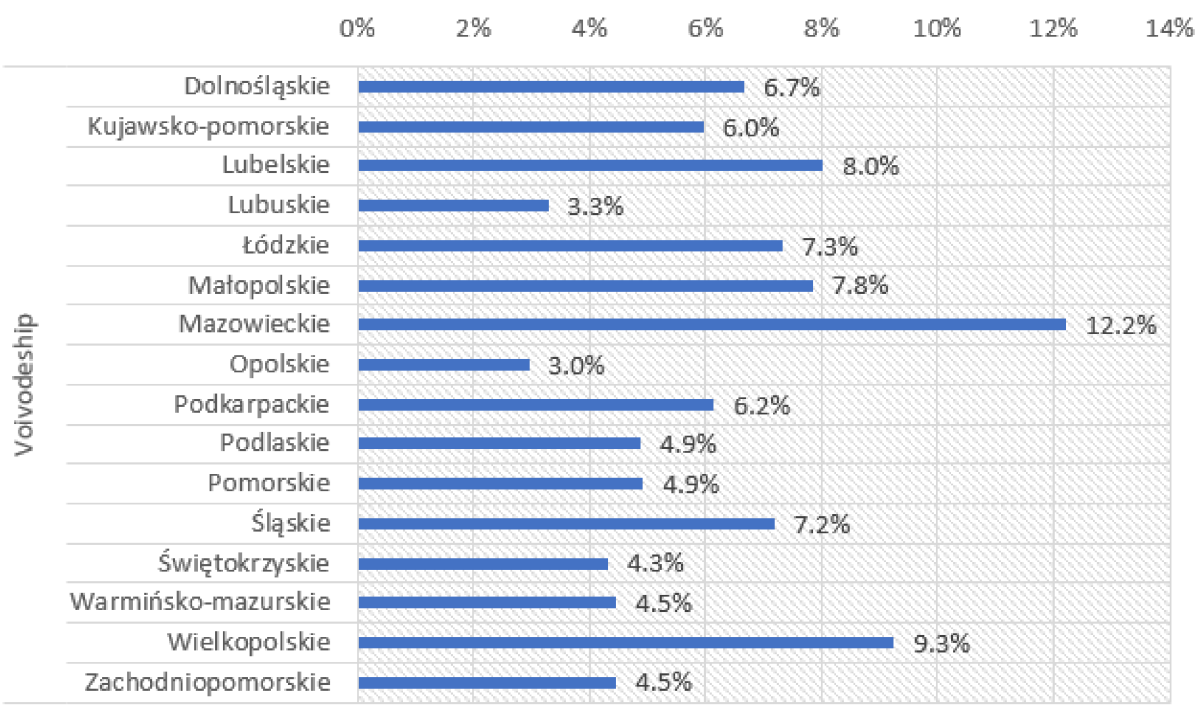

Figure 3. Characteristics of surveyed units in terms of Polish voivodeship. Source: authors' study.

\section{Results and Discussion}

5.1. Relationship between the Assessment of the Development of the Cycling Network with the Type of Commune and the Number of its Inhabitants

The aim of the study was first to find out whether the type of municipality and the number of its inhabitants were associated with the introduction of measures to reduce the use of cars in municipalities. For this purpose, a series of analyses were performed with Pearson's $\chi^{2}$ tests. Table 2 presents the results of Pearson's $\chi^{2}$ test analyses for the association of municipality type with measures to reduce auto use, which were found to be statistically significant at $p<0.001$. Cities with county rights followed by municipalities were by far the most likely to take measures to reduce car use. Municipalities varied the most in terms of having bicycle and scooter rentals on offer $V=0.37$.

Table 2. Results of Pearson's $\chi^{2}$ test analyses for the association of municipality type with measures to reduce car use.

\begin{tabular}{|c|c|c|c|c|c|c|}
\hline $\begin{array}{l}\text { In Order to Reduce the Use of Cars, } \\
\text { the Municipality: }\end{array}$ & $\begin{array}{c}\text { Rural } \\
\text { Municipalities }\end{array}$ & $\begin{array}{l}\text { Urban-Rural } \\
\text { Municipalities }\end{array}$ & $\begin{array}{c}\text { Urban } \\
\text { Municipalities }\end{array}$ & $\begin{array}{l}\text { Cities with } \\
\text { County Rights }\end{array}$ & $p$ & $V$ \\
\hline Builds cycle paths & $48.8 \%$ & $70.6 \%$ & $83.0 \%$ & $98.1 \%$ & 0.000 & 0.29 \\
\hline Offers bicycle/scooter rentals & $3.7 \%$ & $11.7 \%$ & $22.0 \%$ & $66.0 \%$ & 0.000 & 0.37 \\
\hline $\begin{array}{l}\text { Has a park \& ride facility on its } \\
\text { territory located close to public } \\
\text { transport points }\end{array}$ & $7.3 \%$ & $13.5 \%$ & $29.6 \%$ & $39.6 \%$ & 0.000 & 0.25 \\
\hline $\begin{array}{l}\text { Offers carsharing and/or } \\
\text { promotes carpooling }\end{array}$ & $0.4 \%$ & $0.9 \%$ & $2.2 \%$ & $17.0 \%$ & 0.000 & 0.25 \\
\hline None of the above & $48.9 \%$ & $26.3 \%$ & $14.8 \%$ & $1.9 \%$ & 0.000 & 0.29 \\
\hline
\end{tabular}

$p$-level of statistical significance, $V$-Cramer's V relationship strength. Source: authors' study.

It also examined whether the number of residents in municipalities varied the actions the municipality took to reduce auto use (Table 3). Again, the results of Pearson's $\chi^{2}$ test analyses were found to be statistically significant at $p<0.001$. Municipalities with more than 100,000 inhabitants were by far the most likely to undertake actions aimed at limiting the use of cars. Municipalities with large populations were by far the most likely to offer bike/scooter rentals $V=0.33$ and to build bike lanes $V=0.33$. 
Table 3. Results of Pearson's $\chi^{2}$ tests for the relationship between the municipality's population and measures to reduce car use.

\begin{tabular}{|c|c|c|c|c|c|}
\hline $\begin{array}{l}\text { In Order to Reduce the Use of Cars, } \\
\text { the Municipality: }\end{array}$ & $\begin{array}{l}\text { Up to } 10,000 \\
\text { Inhabitants }\end{array}$ & $\begin{array}{l}\text { Up to } 100,000 \\
\text { Inhabitants }\end{array}$ & $\begin{array}{l}\text { More than 100,000 } \\
\text { Inhabitants }\end{array}$ & $p$ & $V$ \\
\hline Builds cycle paths & $47.3 \%$ & $80.1 \%$ & $100.0 \%$ & 0.000 & 0.33 \\
\hline Offers bicycle/scooter rentals & $4.6 \%$ & $15.3 \%$ & $85.2 \%$ & 0.000 & 0.34 \\
\hline $\begin{array}{l}\text { Has a park \& ride facility on its } \\
\text { territory located close to public } \\
\text { transport points }\end{array}$ & $5.2 \%$ & $23.0 \%$ & $59.3 \%$ & 0.000 & 0.31 \\
\hline $\begin{array}{l}\text { Offers carsharing and/or } \\
\text { promotes carpooling }\end{array}$ & $0.5 \%$ & $1.3 \%$ & $25.9 \%$ & 0.000 & 0.27 \\
\hline None of the above & $50.3 \%$ & $17.1 \%$ & $0.0 \%$ & 0.000 & 0.34 \\
\hline
\end{tabular}

$p$-level of statistical significance, $V$-Cramer's V relationship strength. Source: authors' study.

\subsection{The Relationship between the Green Space Development Score and the Type of Municipality and Its Population}

In order to verify hypothesis 2 , a series of Pearson's $\chi^{2}$ tests were performed. First of all, we checked whether communes from some provinces undertook actions aimed at developing green areas particularly often. From the results presented in Table 4 , it can be concluded that the greatest differences were between the municipalities from different provinces, especially in terms of conducting regular plantings with a predominance of native plant species $p<0.001 ; V=0.20$. Such plantings were most often made in communes located in the following voivodeships: Kujawsko-Pomorskie, Opolskie, Pomorskie, Wielkopolskie and Zachodniopomorskie, and least often in communes in Podlaskie and Lubuskie. In general, the communes in the Kujawsko-Pomorskie, Pomorskie and Wielkopolskie voivodeships most often undertook actions to increase the number of green areas.

Table 4. Results of Pearson's $\chi^{2}$ tests for the relationship between the type of province and measures to increase the number of green areas.

\begin{tabular}{|c|c|c|c|c|c|}
\hline $\begin{array}{c}\text { In Order to Increase the } \\
\text { Amount of Green Areas, } \\
\text { the Municipality: }\end{array}$ & $\begin{array}{l}\text { Maintains Regular } \\
\text { Plantings with a } \\
\text { Predominance of } \\
\text { Native Plant Species }\end{array}$ & $\begin{array}{c}\text { Manages and } \\
\text { Maintains Flower } \\
\text { Meadows }\end{array}$ & $\begin{array}{l}\text { Manages/Greens } \\
\text { Nonstandard } \\
\text { Surfaces }\end{array}$ & $\begin{array}{l}\text { Replaces Lawns } \\
\text { with Ground Cover }\end{array}$ & $\begin{array}{l}\text { None of } \\
\text { the above }\end{array}$ \\
\hline Dolnośląskie & $65.5 \%$ & $23.9 \%$ & $16.9 \%$ & $16.9 \%$ & $21.8 \%$ \\
\hline Kujawsko-pomorskie & $78.7 \%$ & $17.3 \%$ & $21.3 \%$ & $9.4 \%$ & $12.6 \%$ \\
\hline Lubelskie & $49.1 \%$ & $10.5 \%$ & $16.4 \%$ & $4.1 \%$ & $41.5 \%$ \\
\hline Lubuskie & $64.3 \%$ & $27.1 \%$ & $20.0 \%$ & $20.0 \%$ & $24.3 \%$ \\
\hline Łódzkie & $57.7 \%$ & $12.8 \%$ & $14.7 \%$ & $6.4 \%$ & $34.0 \%$ \\
\hline Małopolskie & $54.5 \%$ & $19.2 \%$ & $21.6 \%$ & $10.8 \%$ & $31.1 \%$ \\
\hline Mazowieckie & $55.4 \%$ & $16.5 \%$ & $17.3 \%$ & $13.5 \%$ & $36.2 \%$ \\
\hline Opolskie & $76.2 \%$ & $31.7 \%$ & $20.6 \%$ & $11.1 \%$ & $20.6 \%$ \\
\hline Podkarpackie & $68.7 \%$ & $16.8 \%$ & $16.0 \%$ & $7.6 \%$ & $21.4 \%$ \\
\hline Podlaskie & $46.2 \%$ & $18.3 \%$ & $23.1 \%$ & $3.8 \%$ & $41.3 \%$ \\
\hline Pomorskie & $76.2 \%$ & $31.4 \%$ & $17.1 \%$ & $16.2 \%$ & $18.1 \%$ \\
\hline Śląskie & $66.7 \%$ & $28.1 \%$ & $19.0 \%$ & $10.5 \%$ & $25.5 \%$ \\
\hline Świętokrzyskie & $54.3 \%$ & $13.0 \%$ & $21.7 \%$ & $5.4 \%$ & $31.5 \%$ \\
\hline Warmińsko-mazurskie & $68.4 \%$ & $22.1 \%$ & $15.8 \%$ & $5.3 \%$ & $23.2 \%$ \\
\hline Wielkopolskie & $80.7 \%$ & $22.8 \%$ & $17.8 \%$ & $12.7 \%$ & $14.7 \%$ \\
\hline Zachodniopomorskie & $70.5 \%$ & $24.2 \%$ & $18.9 \%$ & $12.6 \%$ & $24.2 \%$ \\
\hline$p$ & 0.000 & 0.000 & 0.000 & 0.000 & 0.000 \\
\hline$V$ & 0.22 & 0.15 & 0.06 & 0.14 & 0.20 \\
\hline
\end{tabular}


It was also checked whether the type of municipality was linked to the measures introduced in the municipality to increase the number of green areas. The results of $\chi^{2}$ Pearson's test analyses turned out to be statistically significant (Table 5), and on their basis it can be concluded that cities with county rights and then urban municipalities increased the number of green areas to the greatest extent. The types of municipalities studied differed the most in the management and maintenance of flower meadows $V=0.41$ and the use of cover greens $V=0.30$.

Table 5. Results of Pearson's $\chi^{2}$ tests for the relationship between type of municipality and measures to increase the number of green areas.

\begin{tabular}{|c|c|c|c|c|c|c|}
\hline $\begin{array}{l}\text { In Order to Increase the Amount of } \\
\text { Green Areas, the Municipality: }\end{array}$ & $\begin{array}{c}\text { Rural } \\
\text { Municipalities }\end{array}$ & $\begin{array}{l}\text { Urban-Rural } \\
\text { Municipalities }\end{array}$ & $\begin{array}{c}\text { Urban } \\
\text { Municipalities }\end{array}$ & $\begin{array}{l}\text { City with } \\
\text { County Rights }\end{array}$ & $p$ & $V$ \\
\hline $\begin{array}{l}\text { Maintains regular plantings with a } \\
\text { predominance of native plant species }\end{array}$ & $54.1 \%$ & $75.0 \%$ & $84.8 \%$ & $86.8 \%$ & 0.000 & 0.25 \\
\hline Manages and maintains flower meadows & $9.7 \%$ & $25.4 \%$ & $51.1 \%$ & $81.1 \%$ & 0.000 & 0.41 \\
\hline Manages/greens nonstandard surfaces & $13.6 \%$ & $22.6 \%$ & $26.9 \%$ & $50.9 \%$ & 0.000 & 0.19 \\
\hline Replaces lawns with ground cover & $4.4 \%$ & $13.7 \%$ & $29.1 \%$ & $41.5 \%$ & 0.000 & 0.30 \\
\hline None of the above & $37.2 \%$ & $14.0 \%$ & $8.1 \%$ & $7.5 \%$ & 0.000 & 0.28 \\
\hline
\end{tabular}

$p$-level of statistical significance, $V$-Cramer's V relationship strength. Source: authors' study.

Similarly, the relationship between the number of inhabitants of communes and the increase in the number of green areas was examined using Pearson's $\chi^{2}$ tests. Again, statistically significant relationships were demonstrated (Table 6). Increasing the number of green areas was most common in municipalities with a population over 100,000. Communities differed particularly in the management and maintenance of $V=0.34$ flower meadows.

Table 6. Results of Pearson's $\chi^{2}$ tests for the relationship between the number of inhabitants of a municipality and measures to increase the number of green areas.

\begin{tabular}{cccc}
\hline $\begin{array}{c}\text { In Order to Increase the Amount of } \\
\text { Green Areas, the Municipality: }\end{array}$ & $\begin{array}{c}\text { Up to 10 Thousand } \\
\text { Inhabitants }\end{array}$ & $\begin{array}{c}\text { Up to 100 Thousand } \\
\text { Inhabitants }\end{array}$ & $\begin{array}{c}\text { More than 100 } \\
\text { Thousand } \\
\text { Inhabitants }\end{array}$ \\
\hline Maintains regular plantings with a & $53.9 \%$ & $80.5 \%$ & $92.6 \%$ \\
predominance of native plant species & $10.9 \%$ & $34.1 \%$ & $88.9 \%$ \\
Manages and maintains flower meadows & $15.0 \%$ & $22.6 \%$ & $70.4 \%$ \\
Manages/greens nonstandard surfaces & $4.8 \%$ & $19.1 \%$ & 0.000 \\
Replaces lawns with ground cover & $36.0 \%$ & $12.1 \%$ & 0.000 \\
None of the above & 0.000 & $0.18 \%$ \\
\hline
\end{tabular}

$p$-level of statistical significance, $V$-Cramer's V relationship strength. Source: authors' study.

It was also checked whether in municipalities where current budget income per capita is high (above EUR 867), measures to increase green areas are more frequent (Table 7). Such differences between municipalities with different per capita incomes were found in terms of running and maintaining flower meadows $p<0.001 ; V=0.14$, use of cover greens $p<0.001$; $V=0.14$ and no action $p<0.01 ; V=0.06$. In order to increase the number of green areas, flower meadows and ground cover greenery were used more frequently by municipalities with per capita incomes above EUR 867, but the differences were not large.

Additionally, using Pearson's $\chi^{2}$ test analyses, the relationship between the number of employees in the municipality's environmental unit and measures to increase green space was examined. The results of the analyses turned out to be statistically significant (Table 8), which means that such a relationship existed. Municipalities with more than two employees in the environmental unit were more likely to use measures to increase green areas, especially in terms of flower meadows. 
Table 7. Results of Pearson's $\chi^{2}$ tests for the relationship between current budget revenues per capita of the municipality and measures to increase the number of green areas.

\begin{tabular}{ccccc}
\hline $\begin{array}{c}\text { In Order to Increase the Number of Green } \\
\text { Areas, the Municipality: }\end{array}$ & Up to EUR 867 Income & $\begin{array}{c}\text { More than EUR } \\
\text { 867 Income }\end{array}$ & $p$ & $V$ \\
\hline Maintains regular plantings with a & $61.0 \%$ & $66.1 \%$ & 0.014 & 0.05 \\
predominance of native plant species & $14.2 \%$ & $25.1 \%$ & 0.000 & 0.14 \\
Manages and maintains flower meadows & $17.4 \%$ & $19.2 \%$ & 0.275 & 0.02 \\
Manages/greens nonstandard surfaces & $5.8 \%$ & $14.4 \%$ & 0.000 & 0.009 \\
Replaces lawns with ground cover & $29.9 \%$ & $24.8 \%$ & 0.06 \\
None of the above &
\end{tabular}

$p$-level of statistical significance, $V$-Cramer's V relationship strength. Source: authors' study.

Table 8. Results of Pearson's $\chi^{2}$ test analyses for the relationship between the number of employees in the municipality's environmental unit and measures to increase the amount of green space.

\begin{tabular}{ccccc}
\hline $\begin{array}{c}\text { In Order to Increase the Number of Green } \\
\text { Areas, the Municipality: }\end{array}$ & Up to 2 Employees: & More than 2 Employees: & $p$ & $V$ \\
\hline Maintains regular plantings with a & $56.9 \%$ & $77.7 \%$ & 0.000 & 0.20 \\
predominance of native plant species & $12.7 \%$ & $35.0 \%$ & 0.000 & 0.26 \\
Manages and maintains flower meadows & $15.1 \%$ & $24.9 \%$ & 0.000 & 0.12 \\
Manages/greens nonstandard surfaces & $6.4 \%$ & $18.6 \%$ & 0.000 & 0.19 \\
Replaces lawns with ground cover & $33.1 \%$ & $15.0 \%$ & 0.19 \\
None of the above & & & 0.000 \\
\hline
\end{tabular}

$p$-level of statistical significance, $V$-Cramer's V relationship strength. Source: authors' study.

5.3. Relationship between the Green Architecture Development Score and the Type of Municipality and Its Population

Another important proecological aspect in the municipalities is the development of green architecture. The aim of the survey was to find out which municipalities are implementing measures for "green" architectural landscape to the greatest extent. Table 9 shows the results of Pearson's $\chi^{2}$ test analyses for the association of province type with measures for "green" architectural landscape. These analyses show that provinces differed in their use of road-pollution-tolerant vegetation on inter-road lanes $p<0.001 ; V=0.17$ or no action $p<0.001 ; V=0.17$. Road-pollution-resistant vegetation was most often used by gminas located in Dolnoślaskie, Kujawsko-Pomorskie and Lubuskie voivodeships and least often by municipalities located in Podkarpackie and Świętokrzyskie voivodeships. In general, no measures for "green" architectural landscape were most often applied by municipalities in Podkarpackie and Warmińsko-Mazurskie voivodeships.

The survey also aimed to find out which municipalities were most likely to implement measures for a "green" architectural landscape. The results of the $\chi^{2}$ Pearson's test analyses proved to be statistically significant (Table 10), which means that the type of municipality differentiated the activities for the "green" architectural landscape. Such measures were most often taken by cities with county rights, particularly in the use of pollution-resistant greenbelts between roads, $V=0.38$, and the maintenance of vegetable or pocket gardens, $V=0.29$.

A further series of analyses showed that the use of measures for "green" architectural landscapes was also linked to the population of the municipality (Table 11). The most frequent measures for a "green" architectural landscape were introduced by large municipalities with over 100,000 inhabitants, and the differences were mainly in the use of pollution-resistant green belts between roads, $V=0.33$, and the maintenance of vegetable and fruit or pocket gardens, $V=0.32$.

It was also checked whether measures for a "green" architectural landscape are more frequent in municipalities where current budget income per capita is high (above EUR 867) (Table 12). Such differences between municipalities with different per capita incomes occurred in terms of the use of pollution-resistant greenbelts between roads, $p<0.001$; $V=0.10$, maintaining vegetable and fruit or pocket gardens, $p<0.001 ; V=0.10$, and no 
action, $p<0.001 ; V=0.09$. More frequent actions towards a "green" architectural landscape were applied by municipalities with per capita income above EUR 867 .

Table 9. Results of Pearson's $\chi^{2}$ tests for the relationship between type of province and measures for "green" architectural landscape.

\begin{tabular}{|c|c|c|c|c|c|}
\hline $\begin{array}{c}\text { For a "Green" } \\
\text { Architectural Landscape, } \\
\text { the Municipality: }\end{array}$ & $\begin{array}{l}\text { Installs Green Bus } \\
\text { Stops/ } \\
\text { Sheds/Roofs }\end{array}$ & $\begin{array}{l}\text { Arranges Interiors and } \\
\text { Communal } \\
\text { Surroundings in } \\
\text { Biophilic Design Style }\end{array}$ & $\begin{array}{c}\text { Uses } \\
\text { Pollution-Resistant } \\
\text { Greenbelts between } \\
\text { Roads }\end{array}$ & $\begin{array}{l}\text { Maintains Open } \\
\text { Vegetable and Fruit } \\
\text { Gardens and/or } \\
\text { Creates and Maintains } \\
\text { Pocket Gardens }\end{array}$ & $\begin{array}{l}\text { None of } \\
\text { the above }\end{array}$ \\
\hline Dolnośląskie & $3.5 \%$ & $7.7 \%$ & $30.3 \%$ & $11.3 \%$ & $58.5 \%$ \\
\hline Kujawsko-pomorskie & $11.8 \%$ & $8.7 \%$ & $31.5 \%$ & $11.0 \%$ & $47.2 \%$ \\
\hline Lubelskie & $6.4 \%$ & $4.7 \%$ & $13.5 \%$ & $2.9 \%$ & $77.8 \%$ \\
\hline Lubuskie & $4.3 \%$ & $8.6 \%$ & $32.9 \%$ & $10.0 \%$ & $61.4 \%$ \\
\hline Łódzkie & $6.4 \%$ & $3.8 \%$ & $18.6 \%$ & $4.5 \%$ & $72.4 \%$ \\
\hline Małopolskie & $3.6 \%$ & $6.6 \%$ & $19.2 \%$ & $9.6 \%$ & $71.3 \%$ \\
\hline Mazowieckie & $5.8 \%$ & $6.9 \%$ & $18.1 \%$ & $8.5 \%$ & $71.9 \%$ \\
\hline Opolskie & $6.3 \%$ & $4.8 \%$ & $15.9 \%$ & $9.5 \%$ & $73.0 \%$ \\
\hline Podkarpackie & $5.3 \%$ & $7.6 \%$ & $10.7 \%$ & $6.9 \%$ & $80.2 \%$ \\
\hline Podlaskie & $5.8 \%$ & $11.5 \%$ & $16.3 \%$ & $8.7 \%$ & $68.3 \%$ \\
\hline Pomorskie & $6.7 \%$ & $6.7 \%$ & $21.9 \%$ & $8.6 \%$ & $64.8 \%$ \\
\hline Śląskie & $3.9 \%$ & $8.5 \%$ & $17.6 \%$ & $13.1 \%$ & $71.9 \%$ \\
\hline Świętokrzyskie & $5.4 \%$ & $13.0 \%$ & $10.9 \%$ & $6.5 \%$ & $70.7 \%$ \\
\hline Warmińsko-mazurskie & $5.3 \%$ & $3.2 \%$ & $13.7 \%$ & $6.3 \%$ & $77.9 \%$ \\
\hline Wielkopolskie & $6.1 \%$ & $7.1 \%$ & $27.9 \%$ & $7.1 \%$ & $65.0 \%$ \\
\hline Zachodniopomorskie & $11.6 \%$ & $8.4 \%$ & $25.3 \%$ & $9.5 \%$ & $58.9 \%$ \\
\hline$p$ & 0.258 & 0.365 & 0.000 & 0.187 & 0.000 \\
\hline$V$ & 0.09 & 0.09 & 0.17 & 0.10 & 0.17 \\
\hline
\end{tabular}

$p$-level of statistical significance, $V$-Cramer's V relationship strength. Source: authors' study.

Table 10. Results of Pearson's $\chi^{2}$ tests for the relationship between type of municipality and measures for a "green" architectural landscape.

\begin{tabular}{|c|c|c|c|c|c|c|}
\hline $\begin{array}{l}\text { For a "Green" Architectural } \\
\text { Landscape, the Municipality: }\end{array}$ & $\begin{array}{c}\text { Rural } \\
\text { Municipalities }\end{array}$ & $\begin{array}{l}\text { Urban-Rural } \\
\text { Municipalities }\end{array}$ & $\begin{array}{c}\text { Urban } \\
\text { Municipalities }\end{array}$ & $\begin{array}{l}\text { City with } \\
\text { County Rights }\end{array}$ & $p$ & $V$ \\
\hline Installs green bus stops/sheds/roofs & $5.1 \%$ & $4.9 \%$ & $8.1 \%$ & $32.1 \%$ & 0.000 & 0.18 \\
\hline $\begin{array}{l}\text { Arranges interiors and communal } \\
\text { surroundings in biophilic design style }\end{array}$ & $5.8 \%$ & $8.1 \%$ & $10.3 \%$ & $18.9 \%$ & 0.000 & 0.09 \\
\hline $\begin{array}{l}\text { Uses pollution-resistant greenbelts } \\
\text { between roads }\end{array}$ & $9.7 \%$ & $28.5 \%$ & $45.7 \%$ & $77.4 \%$ & 0.000 & 0.38 \\
\hline $\begin{array}{l}\text { Maintains open vegetable and fruit } \\
\text { gardens and/or creates and maintains } \\
\text { pocket gardens }\end{array}$ & $3.7 \%$ & $10.3 \%$ & $19.3 \%$ & $47.2 \%$ & 0.000 & 0.29 \\
\hline None of the above & $79.7 \%$ & $59.2 \%$ & $42.2 \%$ & $15.1 \%$ & 0.000 & 0.34 \\
\hline
\end{tabular}

$p$-level of statistical significance, $V$-Cramer's V relationship strength. Source: authors' study.

Table 11. Results of Pearson's $\chi^{2}$ tests for the relationship between the municipality's population and measures for a "green" architectural landscape.

\begin{tabular}{|c|c|c|c|c|c|}
\hline $\begin{array}{l}\text { For a "Green" Architectural Landscape, } \\
\text { the Municipality: }\end{array}$ & $\begin{array}{l}\text { Up to } 10,000 \\
\text { Inhabitants }\end{array}$ & $\begin{array}{l}\text { Up to } 100,000 \\
\text { Inhabitants }\end{array}$ & $\begin{array}{l}\text { More than } 100,000 \\
\text { Inhabitants }\end{array}$ & $p$ & $V$ \\
\hline Installs green bus stops/sheds/roofs & $5.1 \%$ & $6.0 \%$ & $51.9 \%$ & 0.000 & 0.22 \\
\hline $\begin{array}{l}\text { Arranges interiors and communal } \\
\text { surroundings in biophilic design style }\end{array}$ & $5.4 \%$ & $9.8 \%$ & $25.9 \%$ & 0.000 & 0.12 \\
\hline $\begin{array}{l}\text { Uses pollution-resistant greenbelts } \\
\text { between roads }\end{array}$ & $11.5 \%$ & $33.6 \%$ & $88.9 \%$ & 0.000 & 0.33 \\
\hline $\begin{array}{l}\text { Maintains open vegetable and fruit } \\
\text { gardens and/or creates and maintains } \\
\text { pocket gardens }\end{array}$ & $4.3 \%$ & $12.9 \%$ & $77.8 \%$ & 0.000 & 0.32 \\
\hline None of the above & $78.3 \%$ & $53.4 \%$ & $7.4 \%$ & 0.000 & 0.30 \\
\hline
\end{tabular}


Table 12. Results of Pearson's $\chi^{2}$ tests for the relationship between current budget revenues per capita of the municipality and measures for a "green" architectural landscape.

\begin{tabular}{ccccc}
\hline $\begin{array}{c}\text { For a "Green" Architectural Landscape, } \\
\text { the Municipality: }\end{array}$ & Up to EUR 867 Income & $\begin{array}{c}\text { More than EUR } \\
\text { 867 Income }\end{array}$ & $p$ & $V$ \\
\hline $\begin{array}{c}\text { Installs green bus stops/sheds/roofs } \\
\text { Arranges interiors and communal surroundings }\end{array}$ & $5.8 \%$ & $6.2 \%$ & 0.719 & 0.01 \\
in biophilic design style & $6.8 \%$ & $7.5 \%$ & 0.536 & 0.01 \\
Uses pollution-resistant greenbelts between roads & $15.7 \%$ & $24.1 \%$ & 0.000 & 0.10 \\
$\quad$ Maintains open vegetable and fruit gardens & $5.4 \%$ & $10.7 \%$ & 0.000 & 0.000 \\
and/or creates and maintains pocket gardens & $73.2 \%$ & $64.6 \%$ & 0.09 \\
$\quad$ None of the above &
\end{tabular}

$p$-level of statistical significance, $V$-Cramer's V relationship strength. Source: authors' study.

Additionally, using Pearson's $\chi^{2}$ test analyses, the relationship between the number of employees in the municipality's environmental unit and activities for a "green" architectural landscape was examined. Such relationships were found to be statistically significant (Table 13). More frequent activities for "green" architectural landscaping were undertaken in municipalities with more than two employees in the environmental protection unit, particularly in the use of roadside pollution-resistant vegetation on median strips, $V=0.22$, and maintenance of open vegetable and fruit gardens and/or creation and maintenance of pocket gardens, $V=0.17$.

Table 13. Results of Pearson's $\chi^{2}$ tests for the relationship between the number of employees in the municipality's environmental unit and activities for a "green" architectural landscape.

\begin{tabular}{|c|c|c|c|c|}
\hline $\begin{array}{c}\text { For a "Green" Architectural Landscape, } \\
\text { the Municipality: }\end{array}$ & Up to 2 Employees: & More than 2 Employees: & $p$ & $V$ \\
\hline Installs green bus stops/sheds/roofs & $5.0 \%$ & $8.0 \%$ & 0.006 & 0.06 \\
\hline $\begin{array}{l}\text { Arranges interiors and communal surroundings } \\
\text { in biophilic design style }\end{array}$ & $5.7 \%$ & $10.2 \%$ & 0.000 & 0.08 \\
\hline Uses pollution-resistant greenbelts between roads & $13.9 \%$ & $33.1 \%$ & 0.000 & 0.22 \\
\hline $\begin{array}{l}\text { Maintains open vegetable and fruit gardens } \\
\text { and/or creates and maintains pocket gardens }\end{array}$ & $5.0 \%$ & $14.9 \%$ & 0.000 & 0.17 \\
\hline None of the above & $75.2 \%$ & $55.2 \%$ & 0.000 & 0.20 \\
\hline
\end{tabular}

$p$-level of statistical significance, $V$-Cramer's $\mathrm{V}$ relationship strength. Source: authors' study.

5.4. Relationship between the Evaluation of Solutions for Improving Thermal Comfort with the Type of Municipality and the Number of Its Inhabitants

An assumption of the study was also that larger municipalities, with more inhabitants, are more likely to introduce measures to reduce the effects of heat and to improve thermal comfort. The association of these activities with the type of municipalities was examined using Pearson's $\chi^{2}$ test analyses, and the results of the analyses were found to be statistically significant (Table 14). Most actions to reduce the effects of heat and to improve thermal comfort were taken by cities with county rights, followed by municipalities, while the least frequent were actions taken by rural municipalities. The greatest differences between municipalities in terms of actions to reduce the effects of heat and to improve thermal comfort were in terms of introducing blue-green infrastructure elements in close residential areas, $V=0.27$.

Similarly, the associations between the number of inhabitants of the municipality and actions to reduce the effects of heat and for the improvement of thermal comfort were examined by means of $\chi^{2}$ Pearson's test analyses, and the results proved to be statistically significant (Table 15). It may be noted that measures to reduce noise emissions were most often taken by municipalities with a population over 100,000, while the differences between smaller municipalities were not so significant. The greatest differences between municipalities were shown in terms of the introduction of blue-green infrastructure elements in close residential development $V=0.30$. 
Table 14. Results of Pearson's $\chi^{2}$ tests for the association between municipality type and measures to reduce the effects of heat and to improve thermal comfort.

\begin{tabular}{|c|c|c|c|c|c|c|}
\hline $\begin{array}{l}\text { In Order to Reduce the Effects of } \\
\text { Heat and to Improve Thermal } \\
\text { Comfort, the Municipality: }\end{array}$ & $\begin{array}{c}\text { Rural } \\
\text { Municipalities }\end{array}$ & $\begin{array}{l}\text { Urban-Rural } \\
\text { Municipalities }\end{array}$ & $\begin{array}{c}\text { Urban } \\
\text { Municipalities }\end{array}$ & $\begin{array}{c}\text { City with } \\
\text { County Rights }\end{array}$ & $p$ & $V$ \\
\hline $\begin{array}{l}\text { Introduces elements of blue-green } \\
\text { infrastructure in close } \\
\text { residential development }\end{array}$ & $3.1 \%$ & $9.6 \%$ & $17.0 \%$ & $41.5 \%$ & 0.000 & 0.27 \\
\hline $\begin{array}{l}\text { Modifies reflective road and street } \\
\text { surfaces/increases albedo by } \\
\text { modifying road and pavement } \\
\text { surfaces or uses permeable surfaces }\end{array}$ & $7.7 \%$ & $8.9 \%$ & $14.3 \%$ & $28.3 \%$ & 0.000 & 0.13 \\
\hline Install floating gardens & $0.1 \%$ & $1.6 \%$ & $0.9 \%$ & $9.4 \%$ & 0.000 & 0.17 \\
\hline Restores and irrigates wetlands & $0.5 \%$ & $1.4 \%$ & $0.9 \%$ & $3.8 \%$ & 0.039 & 0.06 \\
\hline None of the above & $90.2 \%$ & $82.8 \%$ & $74.0 \%$ & $47.2 \%$ & 0.000 & 0.23 \\
\hline
\end{tabular}

$p$-level of statistical significance, $V$-Cramer's V relationship strength. Source: authors' study.

Table 15. Results of Pearson's $\chi^{2}$ tests for the relationship between the number of inhabitants of a municipality and measures to reduce the effects of heat and to improve thermal comfort.

\begin{tabular}{|c|c|c|c|c|c|}
\hline $\begin{array}{l}\text { In Order to Reduce the Effects of Heat } \\
\text { and to Improve Thermal Comfort, } \\
\text { the Municipality: }\end{array}$ & $\begin{array}{l}\text { Up to } 10,000 \\
\text { Inhabitants }\end{array}$ & $\begin{array}{l}\text { Up to } 100,000 \\
\text { Inhabitants }\end{array}$ & $\begin{array}{l}\text { More than } 100,000 \\
\text { Inhabitants }\end{array}$ & $p$ & $V$ \\
\hline $\begin{array}{l}\text { Introduces elements of blue-green } \\
\text { infrastructure in close } \\
\text { residential development }\end{array}$ & $4.0 \%$ & $11.0 \%$ & $70.4 \%$ & 0.000 & 0.30 \\
\hline $\begin{array}{l}\text { Modifies reflective road and street } \\
\text { surfaces/increases albedo by modifying } \\
\text { road and pavement surfaces or uses } \\
\text { permeable surfaces }\end{array}$ & $6.0 \%$ & $14.0 \%$ & $40.7 \%$ & 0.000 & 0.18 \\
\hline Install floating gardens & $0.3 \%$ & $1.1 \%$ & $18.5 \%$ & 0.000 & 0.23 \\
\hline Restores and irrigates wetlands & $0.7 \%$ & $1.1 \%$ & $7.4 \%$ & 0.001 & 0.08 \\
\hline None of the above & $90.9 \%$ & $78.0 \%$ & $18.5 \%$ & 0.000 & 0.28 \\
\hline
\end{tabular}

$p$-level of statistical significance, $V$-Cramer's V relationship strength. Source: authors' study.

Spearman's rho correlation analysis was also performed to summarize the relationships between the type of municipality and the number of its inhabitants, the current budget revenue per capita in the municipality and the number of employees in the environmental protection unit with the application of proenvironmental solutions by the municipalities. The results of these analyses are presented in Table 16, and it can be concluded that the use of proenvironmental measures was mainly related to the type of municipalities and the number of inhabitants. Larger municipalities have taken a greater number of proenvironmental measures, particularly in reducing car use and increasing green space.

Environmental awareness in Poland remains largely the domain of urban municipalities with higher current budget revenues per capita and in the central and western parts of the country. Podlaskie and Lubuskie voivodeships have the smallest number of plantings, which may be determined by their extensive green areas in comparison with other regions. All large urban agglomerations with more than 100,000 inhabitants are extending cycling routes and offering bicycle and scooter rentals, which coincides with the European trend of eliminating cars from city centers. They also carry out the highest degree of wetland restoration and irrigation, and plant vegetation resistant to road pollution. The number of employees dealing with ecology in the municipality is closely correlated with the level of activity of the municipality in all examined issues. Only Zachodniopomorskie is distinguished in comparison with the whole country, which may be explained by the increased border tourism. One can only hope that the main reason is to improve air quality and not just for aesthetic reasons. Podlaskie and Świętokrzyskie are positively surprising in the high development of biophilic design in public buildings. Lubuskie and Kujawsko-Pomorskie provinces are superior in planting pollution-resistant roadside vegetation, which reduces secondary lift. In the planting of native species, better adapted to the prevailing conditions 
in a given geographical area and more resistant to climatic "turbulences", Wielkopolskie voivodeship is unquestionably in the lead.

Table 16. Results of Spearman's rho correlation analyses for the relationship between type of municipality and number of inhabitants, current budget revenues per capita in the municipality and number of employees in the environmental protection unit and the application of proenvironmental solutions by the municipalities.

\begin{tabular}{ccccc}
\hline Specification & Type of Municipality & $\begin{array}{c}\text { Number of } \\
\text { Inhabitants }\end{array}$ & $\begin{array}{c}\text { Current Budget } \\
\text { Revenue per Capita }\end{array}$ & $\begin{array}{c}\text { Number of Employees in the } \\
\text { Environmental Protection } \\
\text { Unit of the Authority }\end{array}$ \\
\hline $\begin{array}{c}\text { Number of actions in order to reduce } \\
\text { the use of cars }\end{array}$ & $0.36^{* * *}$ & $0.44^{* * *}$ & $0.17^{* * *}$ & $0.26^{* * * *}$ \\
$\begin{array}{c}\text { Number of actions in order to } \\
\text { increase the number of green areas } \\
\text { Number of actions for "green" } \\
\text { architectural landscape }\end{array}$ & $0.41^{* * *}$ & $0.34^{* * *}$ & $0.41^{* * *}$ & $0.16^{* * *}$ \\
$\begin{array}{c}\text { Number of actions in order to reduce } \\
\text { the effects of heat and to improve } \\
\text { thermal comfort }\end{array}$ & $0.19^{* * *}$ & $0.33^{* * *}$ & $0.12^{* * *}$ & $0.23^{* * * *}$ \\
\hline & $0.23^{* * *}$ & $0.12^{* * *}$ & $0.19^{* * *}$ \\
\hline
\end{tabular}

This study also fulfilled its educational function. Half of the respondents (49.9\%) employees from the municipality's environmental unit-learned about NbS directly from the survey. The awareness of these solutions and their applicability creates opportunities for obtaining EU or World Bank funds for them, constituting an added value for all types of municipalities.

\section{Conclusions and Recommendations}

The surveys in this study confirmed the research hypotheses that most Polish municipalities use $\mathrm{NbS}$ without being aware of their European classification. Large urban agglomerations are in the lead due to densely built-up areas, high population density, frequent smog phenomena and the greater expectations of the local community. It is likely that a significant role in undertaking proecological activities by these communes is played by the inhabitants and students of universities themselves, with potentially higher environmental awareness, which could be the subject of further research. An additional advantage of large cities is the presence of specialists in the field of sustainable development.

$\mathrm{NbS}$ are marginal in rural municipalities, which can be explained by the lack of ecological specialists, reduced car traffic and more single-family houses, and thus modest public areas. However, planting protective vegetation along transit and access roads to small towns should be standard. Every municipality, irrespective of size, number of inhabitants and income, should make use of specialist advice on planting, maintaining flower meadows and greening-up difficult areas. The development of guidelines for designing the protection and maintenance of roadside greenery, as is conducted, among others, by the Municipal Greenery Management Board in Poznań, can be a long-term source of information. Little attention is paid by all municipalities to wetland restoration and irrigation. With low groundwater levels in Poland, this is an urgent and priority challenge for the coming years.

$\mathrm{NbS}$ solutions are relatively new and need to be disseminated due to their simple forms of operation, low financial and human resources, and ability to obtain European funds for both micro- and macro-scale projects. The knowledge of NbS solutions is conducive to building an expert base in the commune and creating long-term plans for improving and maintaining the natural values of a given region and particular components of the environment. 


\begin{abstract}
Author Contributions: Conceptualization, E.M.-Z. and I.J.; methodology, E.M.-Z. and I.J.; validation, E.M.-Z. and I.J.; formal analysis, E.M.-Z.; investigation, I.J.; resources, E.M.-Z. and I.J.; data curation, E.M.-Z. and I.J.; writing—original draft preparation, E.M.-Z. and I.J.; writing—review and editing, E.M.-Z. and I.J.; visualization, E.M.-Z. and I.J.; supervision, E.M.-Z. and I.J.; project administration, E.M.-Z. and I.J.; funding acquisition, E.M.-Z. All authors have read and agreed to the published version of the manuscript.
\end{abstract}

Funding: This research received no external funding. The APC was funded by Poznań University of Economics and Business.

Institutional Review Board Statement: Not applicable.

Informed Consent Statement: Not applicable.

Conflicts of Interest: The authors declare no conflict of interest.

\title{
References
}

1. Kessel, D.G. Global Warming-Fact, assessment, countermeasures. J. Pet. Sci. Eng. 2000, 26, 157-168. [CrossRef]

2. Huang, J.-B.; Wang, S.-W.; Yong, L.; Zong-Ci, Z.; Xin-Yu, W. Debates on the causes of global warming. Adv. Clim. Change Res. 2012, 3, 38-44. [CrossRef]

3. De Larminat, P. Earth climate identification vs. anthropic global warming attribution. Ann. Rev. Control 2016, 42, 114-125. [CrossRef]

4. Herndon, J.M. Air Pollution, Not Greenhouse Gases: The Principal Cause of Global Warming. J. Geogr. Environ. Earth Sci. Int. 2018, 17, 1-8. [CrossRef]

5. Houghton, J. The science of global warming. Interdiscip. Sci. Rev. 2001, 26, 247-257. [CrossRef]

6. Jones, C. Earth-An Open Access Journal. Earth 2020, 1, 35. [CrossRef]

7. Soza, E.; Ayres, K. Global Warming and Climate Change. In Proceedings of the MOL2NET'18, Conference on Molecular, Biomedical \& Computational Sciences and Engineering, Basel, Switzerland, 15 January 2018-20 January 2019. [CrossRef]

8. Yogonathan, D. Medical aspects of global warming. Am. J. Ind. Med. 2002, 40, 199-210. [CrossRef]

9. McGushin, A.; Tcholakov, Y.; Hajat, S. Climate Change and Human Health: Health Impacts of Warming of $1.5^{\circ} \mathrm{C}$ and $2{ }^{\circ} \mathrm{C}$. Int. J. Environ. Res. Public Health 2018, 15, 1123. [CrossRef]

10. European Environment Agency. Climate Change, Impacts and Vulnerability in Europe 2012: An Indicator-Based Report, EEA Report Nr 12/2012; Office for Official Publications of the European Union: Luxembourg, 2012.

11. ProVeg International. Food E Pandemics Report; ProVeg: Berlin, Germany, 2020.

12. Barouki, R.; Kogevinas, M.; Audouze, K.; Belesova, K.; Bergman, A.; Birnbaum, L.; Boekhold, S.; Denys, S.; Desseille, C.; Drakvik, E. The COVID-19 pandemic and global environmental change: Emerging research needs. Environ. Int. 2021, 146, 106272. [CrossRef]

13. Seto, K.C.; Fragkias, M.; Güneralp, B.; Reilly, M.K. A meta-analysis of global urban land expansion. PLoS ONE 2011,6 , e23777. [CrossRef]

14. United Nations, Department of Economic and Social Affairs PD. World Urbanization Prospects: The 2014 Revision, Highlights (ST/ESA/SER.A/352); United Nations: New York, NY, USA, 2015.

15. Sudmeier-Rieux, K.; Ash, N.; Murti, R. Environmental Guidance Note for Disaster Risk Reduction Healthy Ecosystems for Human Security and Climate Change Adaptation; IUCN: Gland, Switzerland, 2013. Available online: https://www.iucn.org/sites/dev/ files/content/documents/2013_iucn_bookv2.pdf (accessed on 3 August 2021).

16. Nesshöver, C.; Assmuth, T.; Irvine, K.N.; Rusch, G.M.; Waylen, K.A.; Delbaere, B.; Haase, D.; Jones-Walters, L.; Keune, H.; Kovacs, E.; et al. The science, policy and practice of nature-based solutions: An interdisciplinary perspective. Sci. Total Environ. 2017, 579, 1215-1227. [CrossRef]

17. Raymond, C.M.; Frantzeskaki, N.; Kabisch, N.; Berry, P.; Breil, M.; Nita, M.R.; Geneletti, D.; Calfapietra, C. A framework for assessing and implementing the co-benefits of nature-based solutions in urban areas. Environ. Sci. Policy 2017, 77, 15-247. [CrossRef]

18. Frantzeskaki, N. Seven lessons for planning nature-based solutions in cities. Environ. Sci. Policy 2019, 93, 101-111. [CrossRef]

19. Frantzeskaki, N.; McPhearson, T.; Collier, M.J.; Kendal, D.; Bulkeley, H.; Dumitru, A.; Walsh, C.; Noble, K.; Van Wyk, E.; Ordóñez, C. Nature-based solutions for urban climate change adaptation: Linking science, policy, and practice communities for evidence-based decision-making. BioScience 2019, 69, 455-466. [CrossRef]

20. Faivre, N.; Fritz, M.; Freitas, T.; de Boissezon, B.; Vandewoestijne, S. Nature-Based Solutions in the EU: Innovating with nature to address social, economic and environmental challenges. Environ. Res. 2017, 159, 509-518. [CrossRef]

21. European Commission. Regulation of the European Parliament and of the Council. 4 March 2020. Available online: https: / / ec.europa.eu/info/sites/info/files/commission-proposal-regulation-european-climate-law-march-2020_en.pdf (accessed on 3 August 2021). 
22. Kronenberg, J.; Bergier, T.; Maliszewska, K. The Challenge of Innovation Diffusion: Nature-Based Solutions in Poland. In NatureBased Solutions to Climate Change Adaptation in Urban Areas: Theory and Practice of Urban SustainabilityTransitions; Kabisch, N., Korn, H., Stadler, J., Bonn, A., Eds.; Springer: New York, NY, USA, 2017; pp. 291-305.

23. Cohen-Shacham, E.; Walters, G.; Janzen, C.; Maginnis, S. Nature-Based Solutions to Address Global Societal Challenges; IUCN: Gland, Switzerland, 2016.

24. European Commission. Natured Based Solutions. Available online: https://ec.europa.eu/info/research-and-innovation/ research-area/environment/nature-based-solutions_en (accessed on 3 August 2021).

25. European Commission. COMMISSION STAFF WORKING DOCUMENT. Guidance on a Strategic Framework for Further Supporting the Deployment of EU-Level Green and Blue Infrastructure, SWD(2019) 193 Final. 24 May 2019. Available online: https:/ / ec.europa.eu/environment/nature/ecosystems/pdf/SWD_2019_193_F1_STAFF_WORKING_PAPER_EN_V4_P1 1024680.PDF (accessed on 3 August 2021).

26. Kabisch, N.; Frantzeskaki, N.; Pauleit, S.; Naumann, S.; Davis, M.; Artmann, M.; Haase, D.; Knapp, S.; Korn, H.; Stadler, J.; et al. Nature-based solutions to climate change mitigation and adaptation in urban areas: Perspectives on indicators, knowledge gaps, barriers, and opportunities for action. Ecol. Soc. 2016, 21, 39. [CrossRef]

27. Iwaszuk, E.; Rudik, G.; Duin, L.; Mederake, L. Btękitno-Zielona Infrastruktura dla Łagodzenia Zmian Klimatu—Katalog Techniczny; Ecologic Institute i Fundacja Sendzimira: Krakow, Poland, 2019.

28. Castleton, H.F.; Stovin, V.; Beck, S.B.M.; Davison, J.B. Green roofs; building energy savings and the potential for retrofit. Energy Build. 2010, 42, 1582-1591. [CrossRef]

29. Barton, H.; Grant, M. A health map for the local human habitat. J. R. Soc. Promot. Health 2006, 126, 252-253. [CrossRef]

30. Keniger, L.; Gaston, K.; Irvine, K.; Fuller, R. What are the benefits of interacting with nature? Int. J. Environ. Res. Public Health 2013, 10, 913-935. [CrossRef]

31. United Nations. Resolution Adopted by the General Assembly on 25 September 2015, Transforming Our World: The 2030 Agenda for Sustainable Development. Available online: https://www.un.org/ga/search/view_doc.asp?symbol=A/RES/70/1\&Lang=E (accessed on 3 August 2021).

32. The World Bank. Managing Coasts with Natural Solutions; The World Bank: Washington, DC, USA, 2016. Available online: https:/ / documents1.worldbank.org/curated/en/995341467995379786/pdf/Managing-coasts-with-natural-solutionsguidelines-for-measuring-and-valuing-the-coastal-protection-services-of-mangroves-and-coral-reefs.pdf (accessed on 3 August 2021).

33. The World Bank. Nature-Based Solutions: A Cost-Effective Approach for Disaster Risk and Water Resource Management. Available online: https://www.worldbank.org/en/topic/disasterriskmanagement/brief/nature-based-solutions-cost-effectiveapproach-for-disaster-risk-and-water-resource-management (accessed on 3 August 2021).

34. European Commission. Towards an EU Research and Innovation Policy Agenda for Nature-Based Solutions E Re-Naturing Cities; Publications Office of the European Union: Luxembourg, 2015.

35. European Commission. The European Green Deal COM/2019/640 Final; EC-European Commission: Luxembourg, 2019.

36. Kooijman, E.D.; McQuaid, S.; Rhodes, M.-L.; Collier, M.J.; Pilla, F. Innovatin with Nature: From Nature Based Solutions to Nature Based Enterprise. Available online: https://www.researchgate.net/publication/348781132_Innovating_with_Nature_From_ Nature-Based_Solutions_to_Nature-Based_Enterprises (accessed on 3 August 2021).

37. OECD. OECD Council Recommendation on Water; OECD: Paris, France, 2016.

38. OECD. Natured Based Solutions for Adapting to Water-Related Climate Risks: Policy Perspectives; OECD: Paris, France, 2020.

39. Ministry of the Environment. Strategiczny Plan Adaptacji dla Sektorów i Obszarów Wrażliwych na Zmiany Klimatu do Roku 2020 z Perspektywa do 2030 tzw. SPA2020; Ministerstwo Środowiska: Warszawa, Poland, 2013.

40. Ministry of the Environment. Polityka Ekologiczna Państwa 2030. Available online: https://bip.mos.gov.pl/fileadmin/ user_upload/bip/prawo/projekty/PROJEKT_POLITYKI_EKOLOGICZNEJ_PANSTWA_2030/Projekt_Polityki_ekologicznej_ panstwa_2030.pdf (accessed on 3 August 2021).

41. Kańduła, S.; Przybylska, J. Financial instruments used by Polish municipalities in response to the first wave of COVID-19. Public Organ. Rev. 2021, 21, 665-686. [CrossRef]

42. Act of 8 March 1990 on Local Self-Government (Dz.U. 1990 No. 16. Item 95 with Amendments). Available online: https: / /isap.sejm.gov.pl/isap.nsf/download.xsp/WDU19900160095/U/D19900095Lj.pdf (accessed on 3 August 2021).

43. Ciechanowicz-McLean, J. Zadania i kompetencje gminy w zakresie ochrony środowiska-Kierunki zmian. Gdańskie Studia Prawnicze 2015, 171, 170-179.

44. Wyrębek, H. Zarządzanie ochrona środowiska w jednostkach samorządu terytorialnego na przykładzie gminy. Zesz. Nauk. Akad. Podl. Adm. Zarz. 2010, 11, 47-57.

45. Act of 3 October 2008 on the Provision of Information on the Environment and Its Protection, Public Participation in Environmental Protection and Environmental Impact Assessments (Dz.U. 2008 No. 199 Item 1227 with Amendments). Available online: http:/ /isap.sejm.gov.pl/isap.nsf/download.xsp/WDU20081991227/U/D20081227Lj.pdf (accessed on 3 August 2021).

46. Wolańska, K. Rozwiązania Nature Based Solutions w Miastach-Interview with dr Kornelia Kwiecińska from the University of Life Sciences in Wrocław. Available online: chronmyklimat.pl (accessed on 3 August 2021).

47. Burszta-Adamiak, E. Zielone Dachy Jako Element Zrównoważonych Systemów Odwadniajacych na Terenach Zurbanizowanych; Uniwersytet Przyrodniczy we Wrocławiu: Wrocław, Poland, 2015. 
48. Lafortezza, R.; Chen, J.; Van den Bosch, C.K.; Randrup, T.B. Nature-based solutions for resilient landscapes and cities. Environ. Res. 2018, 165, 431-441. [CrossRef]

49. Kabisch, N.; Korn, H.; Stadler, J.; Bonn, A. Nature-Based Solutions to Climate Change Adaptation in Urban Areas: Linkages between Science, Policy and Practice; Springer: New York, NY, USA, 2017. [CrossRef]

50. Zölch, T.; Henze, L.; Keilholz, P.; Pauleit, S. Regulating urban surface runoff through nature-based solutions-An assessment at the micro-scale. Environ. Res. 2017, 157, 135-144. [CrossRef]

51. Fan, P.; Ouyang, Z.; Basnou, C.; Pino, J.; Park, H.; Chen, J. Nature-based solutions for urban landscapes under postindustrialization and globalization: Barcelona versus Shanghai. Environ. Res. 2017, 156, 272-283. [CrossRef]

52. Van der Jagt, A.P.N.; Szaraz, L.R.; Delshammar, T.; Cvejić, R.; Santos, A.; Goodness, J.; Buijs, A. Cultivating nature-based solutions: The governance of communal urban gardens in the European Union. Environ. Res. 2017, 159, 264-275. [CrossRef]

53. Analiza Sytuacji Społeczno-Ekonomicznej Województwa Lubuskiego w Obszarach Oddziaływania Europejskiego Funduszu Społecznego. 2018. Zielona Góra. Available online: https:/ / rpo.lubuskie.pl/documents/10184/32408/Analiza_sytuacji_EFS_v. 4_19.12.18.pdf/c5c2ba5f-d0f2-4e86-9bc2-378ea832dc3b (accessed on 3 August 2021). 